\title{
Potential role of marine algae extract on 3T3-L1 cell proliferation and differentiation: an in vitro approach
}

\author{
Soundharrajan Ilavenil ${ }^{1 \dagger}$, Da Hye Kim ${ }^{2 \dagger}$, Mayakrishnan Vijayakumar', Srisesharam Srigopalram ${ }^{1}$, Sang Gun Roh ${ }^{3}$, \\ Mariadhas Valan Arasu ${ }^{4}$, Jong Suk Lee ${ }^{5}$ and Ki Choon Choi ${ }^{* *}$
}

\begin{abstract}
Background: From ancient times, marine algae have emerged as alternative medicine and foods, contains the rich source of natural products like proteins, vitamins, and secondary metabolites, especially Chlorella vulgaris (C. vulgaris) contains numerous anti-inflammatory, antioxidants and wound healing substances. Type 2 diabetes mellitus is closely associated with adipogenesis and their factors. Hence, we aimed to investigate the chemical constituents and adipogenic modulatory properties of C. vulgaris in 3T3-L1 pre-adipocytes.

Results: We analysed chemical constituents in ethanolic extract of C. vulgaris (EECV) by LC-MS. Results revealed that the EECV contains few triterpenoids and saponin compounds. Further, the effect of EECV on lipid accumulation along with genes and proteins expressions which are associated with adipogenesis and lipogenesis were evaluated using oil red $\mathrm{O}$ staining, $\mathrm{QPCR}$ and western blot techniques. The data indicated that that EECV treatment increased differentiation and lipid accumulation in 3T3-L1 cells, which indicates positive regulation of adipogenic and lipogenic activity. These increases were associated with up-regulation of PPAR- $\gamma 2$, C/EBP-a, adiponectin, FAS, and leptin mRNA and protein expressions. Also, EECV treatments increased the concentration of glycerol releases as compared with control cells. Troglitazone is a PPAR- $\gamma$ agonist that stimulates the PPAR- $\gamma 2$, adiponectin, and GLUT-4 expressions. Similarly, EECV treatments significantly upregulated PPAR- $\gamma 2$, adiponectin, GLUT-4 expressions and glucose utilization. Further, EECV treatment decreased AMPK-a expression as compared with control and metformin treated cells.
\end{abstract}

Conclusion: The present research findings confirmed that the EECV effectively modulates the lipid accumulation and differentiation in 3T3-L1 cells through AMPK-a mediated signalling pathway.

Keywords: Chlorella vulgaris, Chemical constituents, Adipocyte differentiation, PPAR- $\gamma 2$, AMPK-a

\section{Background}

Adipogenesis is the process which converts the preadipocyte into adipocyte through various mechanisms. In circumstances of positive energy balance, increased energy storage through the conversion of adipocyte from pre-adipocyte by the adipogenesis process $[1,2]$. Adipocytes are mainly involved in the maintenance of energy

\footnotetext{
*Correspondence: choiwh@korea.kr

tSoundharrajan Ilavenil and Da Hye Kim contributed equally to this work

${ }^{1}$ Grassland and Forage Division, National Institute of Animal Science,

RDA, Seonghwan-Eup, Cheonan-Si, Chungnam 330-801, Republic of Korea

Full list of author information is available at the end of the article
}

balance and lipid homoeostasis by releasing free fatty acids and storing triacylglycerols in response to changes in energy demands. For this reason, many researchers have been focused on the increase of adipose tissue mass (hyperplasia) and size of adipocytes (hypertrophy) [3]. Animal and human model studies showed that the metabolic disorder of type 2 diabetes mellitus is closely associated with decreased adipogenesis and adipogenic factors [4]. Insufficient amounts of adipose tissue can result in inadequate free fatty acids storage, which leading to increasing plasma levels of free fatty acids, and a resultant increased fat deposition in muscle and liver, which ultimately leads to make insulin resistance and 
clinical type 2 diabetes [5]. Numerous identified adipogenic factors are involved in the adipogenesis. Among these, peroxisome proliferator-activated receptor- $\gamma 2$ (PPAR $\gamma 2)$, and CCAAT/enhancer binding protein- $\alpha(\mathrm{C} /$ EBP- $\alpha$ ) plays an important role in adipocyte differentiation and lipid accumulation. Further, the activation of these two factors can stimulate adiponectin, adipogenin, leptin, glucose transporter-4 (GLUT-4), fatty acid synthase (FAS), and adipocyte binding protein (aP2) and other gene expression which are associated with lipogenesis and adipogenesis [6]. AMP-activated protein kinase (AMPK) is a hetero-trimer complex, which acts as a sensor of cellular energy [7]. It activated during stresses that deplete the cellular ATP and phosphorylate the catalytic alpha subunit on Thr172 by an upstream kinase. AMPactivated protein kinase is getting activated during the lipolysis process in adipocyte [8-10].

Natural marine products are much important resources for chemical diversity. Recently, numbers of clinical trials have been conducted on these marine products. From ancient times, marine algae have emerged as an alternative medicine and foods in many Asian countries such as South Korea, Japan and China etc. [11]. Chlorella is potent source for protein, lipid soluble vitamins, choline, and dietary fiber. It contains approximately $60 \%$ of protein. The amino acid quantity and nutritional composition of chlorella are similar to egg nutrition's $[12,13]$ and it has many biological properties such as promoting growth rate of animals, production of cytokine and stimulating the immune function [14]. Many studies reported that the Chlorella vulgaris prevents the oxidative stress in mice and stress mediated ulcer [15]. Further, it has antilipidemic and anti-atherosclerotic activity [16]. In addition, C. vulgaris prevents dyslipidemia in wistar rats [17]. The present study, we investigated the impact of ethanolic extract of $C$. vulgaris on adipocyte viability and differentiation in 3T3-L1 cells as a model system.

\section{Results}

Cytotoxicity effect of EECV on 3T3-L1 pre-adipocyte

3T3-L1 cells were treated with various concentrations (5, $10,15,20,25,50$ and $100 \mu \mathrm{g} / \mathrm{ml}$ ) of EECV for $48 \mathrm{~h}$. EECV treatment did not affect the pre-adipocyte viability up to $25 \mu \mathrm{g} / \mathrm{ml}$. However, further increment (50 and $100 \mu \mathrm{g} /$ $\mathrm{ml}$ ) exhibited slight cytotoxic effects on the 3T3-L1 cells as compared with control. Therefore, we considered safe dosage ranges of EECV were from 5 to $25 \mu \mathrm{g} / \mathrm{ml}$ for further experiment (Fig. 1).

\section{EECV enhances differentiation and lipid accumulation in adipocyte}

Microscopic observation revealed that the 3T3-L1 cells were differentiated into mature adipocyte after addition

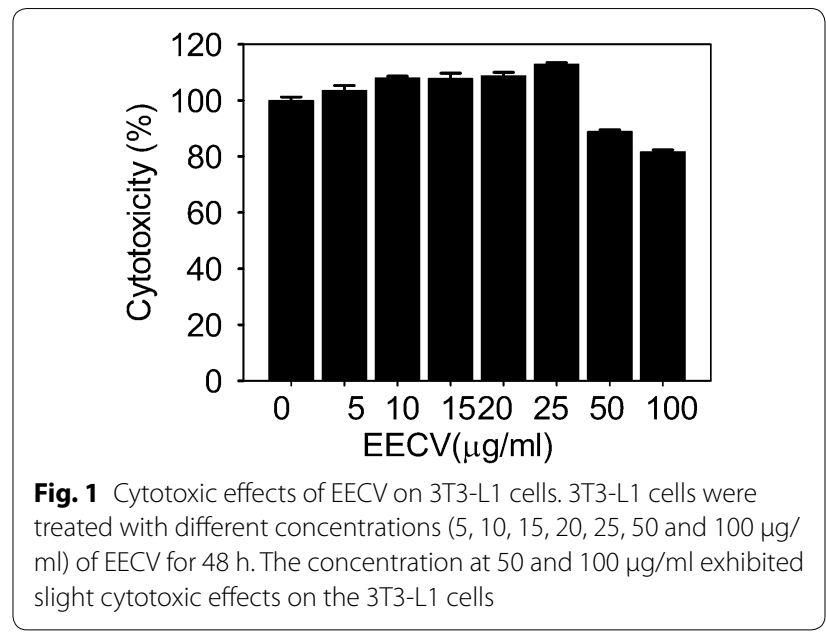

of differentiation induction medium. This differentiation was enhanced by the EECV treatment (Fig. 2A). The prior concentration 5 and $10 \mu \mathrm{g} / \mathrm{ml}$ of EECV treatment did not influence the adipocyte differentiation. The maximum numbers of mature spherical shape adipocyte were observed at a concentration of $25 \mu \mathrm{g} / \mathrm{ml}$ of EECV. The oil Red O staining results showed greater intracellular lipid accumulation in the cells treated with EECV than the control cells (Fig. 2B). The absorbance of the dye extracted from cells showed higher in EECV treated adipocyte as compared with control adipocyte (Fig. 2C). EECV treated adipocyte showed the higher amount of glycerol releases than the control cells $(\mathrm{p} \leq 0.05)$ (Fig. 2D).

\section{EECV up-regulates key transcriptional adipogenic} and lipogenic gene expression

Further, we investigated the effect of EECV on the adipogenesis-related key transcriptional and other-factors using the qPCR technique. Figure 3 shows, EECV treatment increased PPAR $\gamma 2, \mathrm{C} / \mathrm{EBP}-\alpha$, adiponectin, FAS, and leptin mRNA expression as compared with control cell. Further, we confirmed the protein expression of PPAR 2 and $\mathrm{C} / \mathrm{EBP}-\alpha$ by western blot technique. These results evidenced that the EECV upregulates the PPAR 2 and $\mathrm{C} /$ EBP- $\alpha$ protein expressions (Fig. 4).

\section{EECV downregulates AMPK- $\alpha$ activation and upregulates of PPAR 2 protein expression}

The adipocyte treated with EECV exhibited downregulation of AMP-activated protein kinase (pAMPK) and upregulation of PPAR $\gamma 2$ as compared with control cells. Metformin is an agonist for AMPK, which increased AMPK- $\alpha$ and decreased PPAR $\gamma 2$ expression in adipocyte (Fig. 5A). Further, metformin mediated activation of AMPK- $\alpha$ was abolished by the EECV treatment. It 

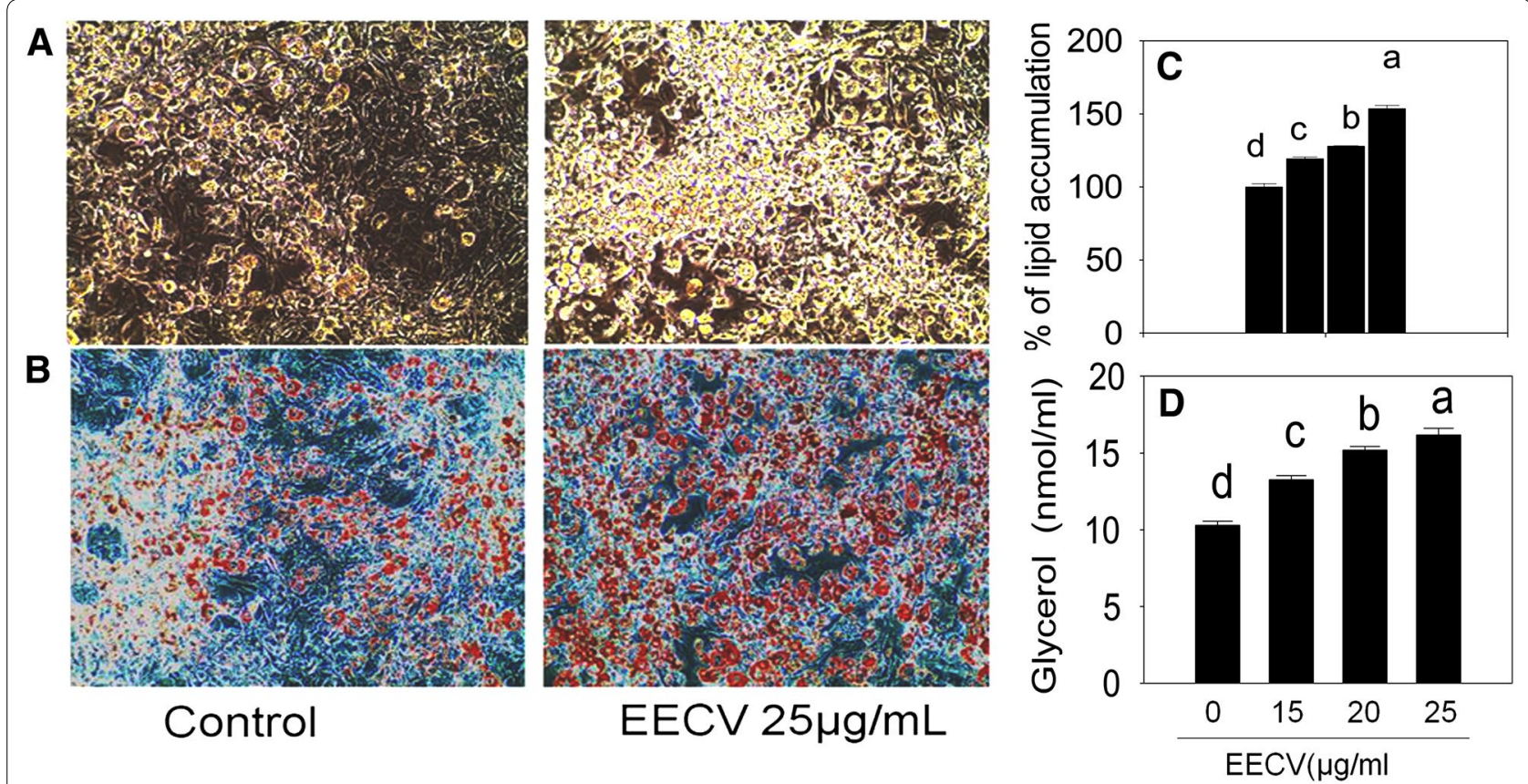

Fig. 2 EECV on adipocytes differentiation and glycerol release. A Differentiation spots in the experimental adipocytes on the 10 th day, B oil red $O$ staining of lipids in experimental adipocytes, C oil red O stained lipid accumulation extracted by $100 \%$ isopropanol. D Glycerol releases from differentiated adipocytes on the10th day. The results represent the mean \pm SEM of six replicates. Different letters $a, b, c, d$, within a treatment indicates significant differences $(p<0.05)$

indicates that EECV treatment stimulates adipocyte differentiation via upregulation of PPAR 2 by inhibition of AMPK- $\alpha$ mediated signal pathway (Fig. $5 \mathrm{~B})$.

\section{EECV increased glucose utilization}

Troglitazone (TZD) is an agonist for PPAR $\gamma$, which stimulates PPAR $\gamma$ expression in the adipocyte. Here, adipocyte treated with troglitazone $(5 \mu \mathrm{M})$ for $48 \mathrm{~h}$ increased PPAR 2 expression and lipid accumulation as compared with control cells. Further, it increased adiponectin and GLUT-4 mRNA expression. Similarly, EECV treatment increased PPAR $\gamma$, adiponectin and GLUT-4 mRNA expression as compared with control cells (Fig. 6A). Further, we confirmed the protein expression patterns of PPAR $\gamma 2$ and adiponectin in TZD and EECV treated adipocyte; it revealed that the EECV stimulates PPARY and adiponectin protein expression like TZD treatment (Fig. 6B). EECV stimulates lipid accumulation in adipocyte similar to troglitazone as compared with control cells (Fig. 6C). In addition, adipocyte treated with EECV significantly increased glucose utilisation as compared with control cells. This utilisation may be due to increasing of adiponectin and GLUT-4 level by the EECV treatment. These results were comparable with troglitazone and insulin treatments (Fig. 6D).
Identification of chemical constituents in extract by LCMS The EECV possesses different types of organic compounds including Cecropiacic acid, briarellin-A, Platycodigenin, Martiriol, Ergost-7-ene-2,3,5,6,9,11,19heptol, Gingerglycolipid-A, gingerglycolipid-B, gingerglycolipid-C (Fig. 7).

\section{Discussion}

Adipocyte differentiation is a process in which pre-adipocyte are developing into mature spherical shape adipocyte which contains more lipids. At the time of adipocyte differentiation, morphological, biochemical characters and lipid accumulation were altered [18].

Natural marine sources have more attraction and attention as pharmacological sources which can be used to develop novel therapeutic agents because of distinct environments of marine life and biological diversity of marine organisms [19]. Many marine compounds possess the different pharmacological application in terms of antibacterial, antidiabetic, anti-inflammatory antiviral and antifungal activities $[20,21]$. In addition, some of the triterpenoid, and saponin has the ability to promotes adipocyte differentiation [22-24]. In the present study, we investigated the ability of the ethanolic extract of C. vulgaris to enhance the adipocyte differentiation 

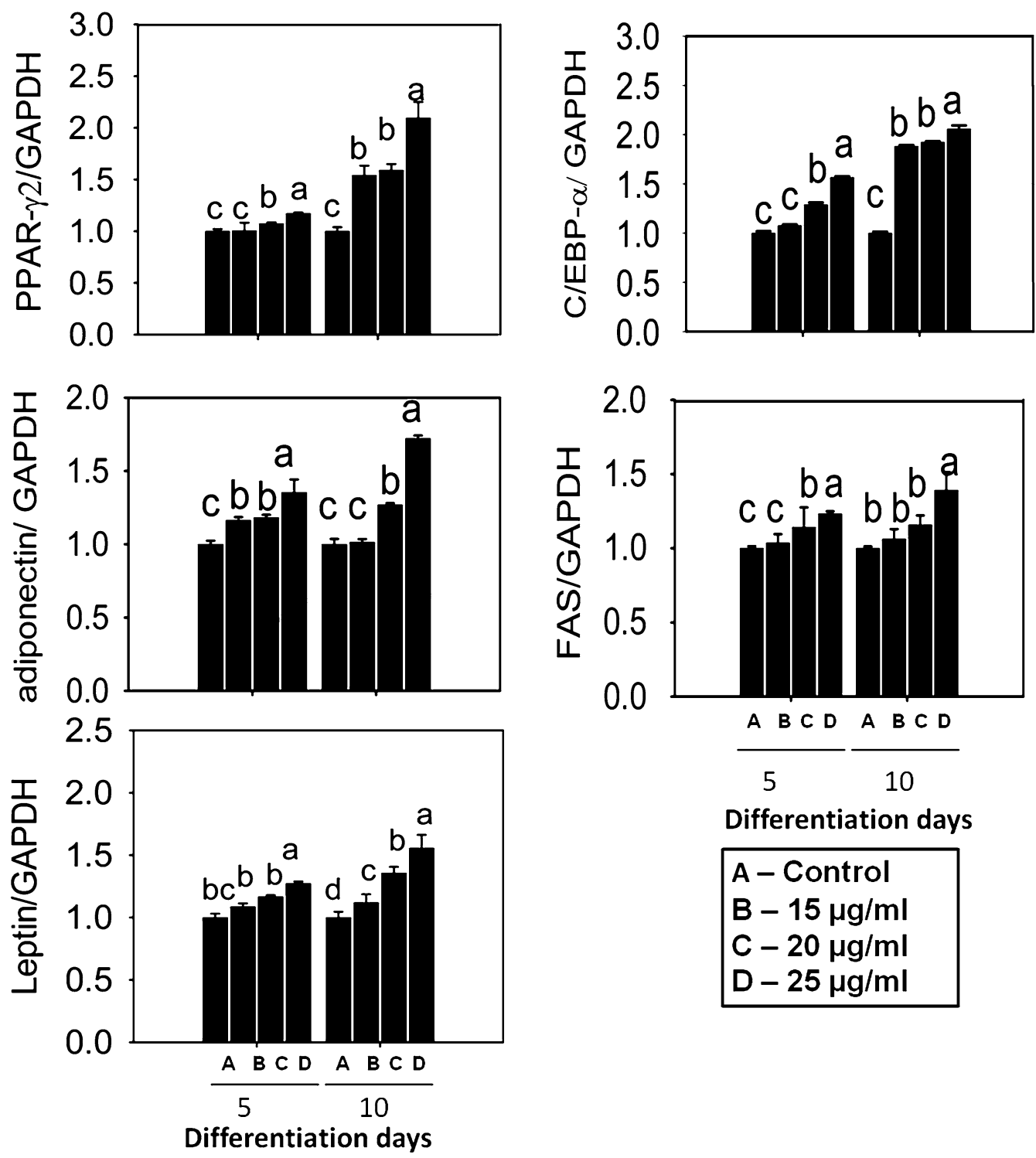

Differentiation days

$$
\begin{aligned}
& \text { A - Control } \\
& B-15 \mu \mathrm{g} / \mathrm{ml} \\
& C-20 \mu \mathrm{g} / \mathrm{ml} \\
& D-25 \mu \mathrm{g} / \mathrm{ml}
\end{aligned}
$$

Fig. 3 Impact of EECV on adipogenic and lipogenic mRNA expression quantified by qPCR. EECV treatment increased PPAR- $\gamma 2$, C/EBP-a, adiponectin, FAS and leptin mRNA expression in a dose dependent manner on the 5 th and 10 th day of differentiation. The results represent the mean \pm SEM of six replicates. Different letters $a, b, c, d$, within a treatment indicates significant differences $(p<0.05)$

and lipid accumulation as promising therapeutic agents for dyslipidemia and type-2 diabetes. EECV treatment increased lipid droplets accumulation as compared with control cells which indicate positive regulation of adipogenesis and lipogenesis by the EECV. Further, LC-MS results revealed that EECV had few di, triterpenoids (Cecropiacic acid; Briarellins-A; Martiriol) and saponin (platycodigenin). It might be a reason for accumulation of lipid in adipocytes.

Further, we investigated the impact of EECV on the key transcriptional factors such as PPAR $\gamma$ and C/EBP- $\alpha$, because of PPAR $\gamma$ and C/EBP- $\alpha$ are much important factors which are working sequentially and co-operatively in stimulating adipogenesis events which lead to accumulation of lipids in the adipocyte [25]. Especially, C/EBP- $\alpha$ has distinct functions in adipocyte differentiation and insulin sensitivity [26]. C/EBP- $\alpha$ plays a major role in the activation and maintenance of PPAR $\gamma$ expression during the adipocyte differentiation. In addition, C/EBP- $\alpha$ stimulates the gene expressions which are involved in the insulin sensitivity, lipogenesis, lipolysis and another encoding gene [27, 28]. Our research findings indicates 

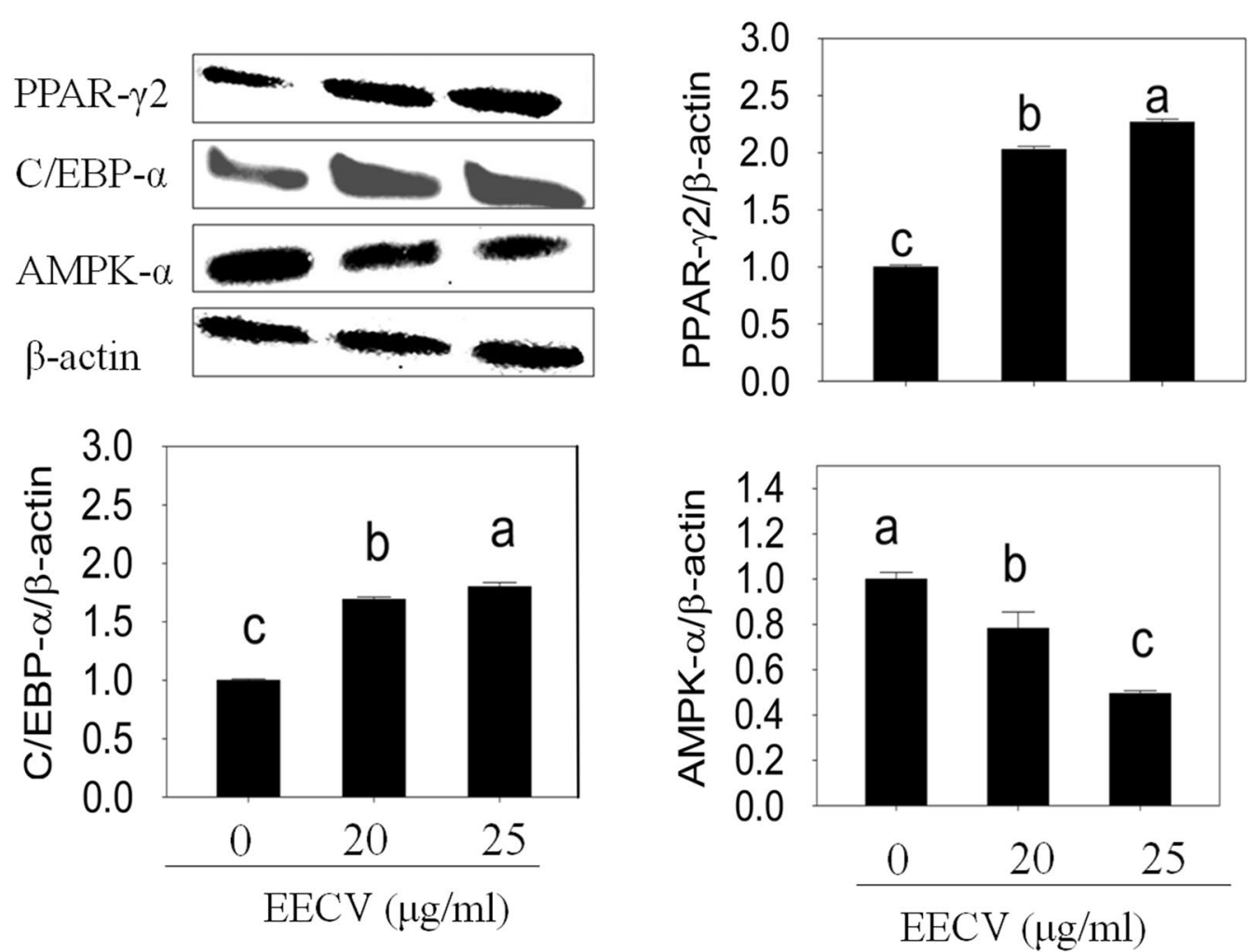

Fig. 4 Effects of EECV on PPAR- $\gamma 2, C / E B P-a$ and AMPK-a protein expression. EECV treatment upregulates PPAR- $\gamma 2, C / E B P-a$ and downregulates AMPK-a protein level on the 10th day. The results represent the mean \pm SEM of three replicates different letters $a, b, c$, within a treatment indicates significant differences $(p<0.05)$

that the increased expression of PPAR 2 stimulate the adipocyte differentiation continuously in EECV treated adipocyte by direct acting on C/EBP- $\alpha$. Similarly, extract from Italian rye grass [29] and Mulberry leaf [30] stimulates the adipocyte differentiation through activation of PPARY and C/EBP- $\alpha$.

Adiponectin is an important hormone that synthesized and expressed exclusively in the differentiated adipocyte. Adiponectin level was increased in the fully differentiated adipocyte. It regulates numbers of metabolic processes either by enhancing insulin sensitivity in muscle and liver or by stimulating fatty acid oxidation in many tissues [31-33]. Over-expression of adiponectin enhances insulin sensitivity in part through hepatic glucose production [34]. Increase of adiponectin mRNA expression in the adipocyte is one of the main criteria for lipid accumulation in the adipocyte. Our finding strongly supports the above said suggestion, in that EECV treatment increased lipid droplet and glycerol accumulation in adipocyte may be due to increasing of adiponectin.

Leptin is a peptide hormone which is exclusively secreted in adipocyte and it has many biological activities such as effects on appetite, food intake, body weight regulation, fertility, reproduction and hematopoiesis [35]. Leptin mRNA is stimulated during adipocyte conversions, which are useful for studying adipocyte differentiation and their function under controlled conditions [36]. The present study, adipocyte supplemented with different concentration of EECV upregulates leptin mRNA expression. This result was strongly concurred with lipid accumulation report, which reveals EECV treatments increased lipid accumulation, because leptin enhance the lipid accumulation in adipocyte [37].

Fatty acid synthase (FAS) a multi-enzyme protein, plays a vital role in the anabolic conversion of dietary carbohydrates to fatty acids and regulation of lipid metabolism $[32,38]$. Fatty acid synthase promotes the synthesis of triglyceride and cytoplasmic accumulation in the adipocyte [39]. The expression of PPAR $\gamma$ and C/EBP- $\alpha$ are much important for activation of other adipocyte specific genes and adipokines such as FAS, leptin, and adiponectin $[40,41]$. Among these, fatty acid synthase is a lipogenic enzyme which involves in the fatty acid synthesis and it's largely upregulated in the cells or tissues [42]. The 3T3-L1 pre-adipocyte are differentiated with IBMX and dexamethasone and acquire the characteristic of fat cells 

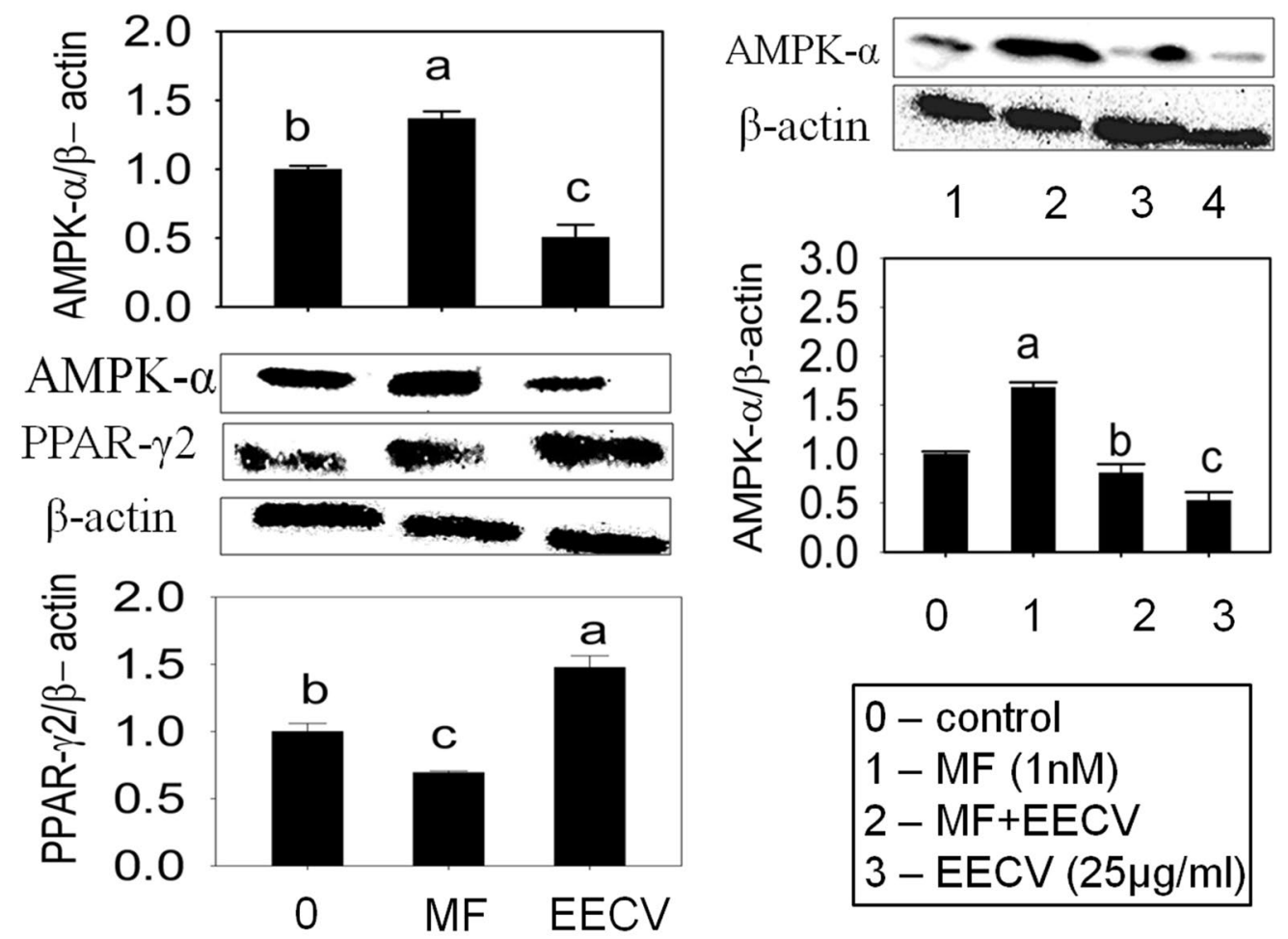

A

B

Fig. 5 Comparative effects between metformin and EECV on AMPK-a and PPAR- $\gamma 2$. A EECV and metformin alone treated adipocytes exhibited down and upregulation of AMPK- $a$ and PPAR- $\gamma 2$ respectively. B Adipocyte treated with metformin (MF) for $48 \mathrm{~h}$, and then treated with EECV for 8 days. Metformin mediated activation of AMPK-a was disturbed by the EECV treatment. The results represent the mean \pm SEM of three replicates different letters $a, b, c, d$, within a treatment indicates significant differences $(p<0.05)$

including responsiveness to insulin and induction of FAS [43]. The present study, we demonstrated that 3T3-L1 cell treated with different concentration of EECV increased expression of FAS mRNA as compared with control cells. This result suggested that the EECV has lipogenic activity by activating FAS mRNA expression.

The AMP-activated protein kinase (AMPK) plays an important role in metabolic energy homeostasis in cells. When it activated, it switches on the catabolic pathways and simultaneously switches off the ATP consuming anabolic pathways [44]. AMPK- $\alpha$ provides an upstream signal of peroxisome proliferator-activated receptor $\gamma$ (PPAR $\gamma$ ), which inhibits the adipocyte differentiation [45, 46]. In addition, AMPK directly modulates fatty acid synthesis and oxidation by changing expression patterns of proteins and enzymes, which involved in the fat metabolism and also AMPK- $\alpha$ regulates pre-adipocyte differentiation [41, 47]. Many reports claimed that the AMPK- $\alpha$ pathway is responsible for the inhibition of adipocyte differentiation by several natural compounds like apigenin dioxinodehydroeckol, Chitin, Ginsenoside, epigallocatechin gallate, 5-Aminoimidazole-4-carboxamide-1- $\beta$-D-ribo-furanoside
(AICAR) [48-53]. The present study, EECV decreased the AMPK- $\alpha$ and increased expression of PPAR $\gamma 2$ during differentiation, whereas addition of metformin is an agonist for AMPK- $\alpha$ exhibited downregulation of PPAR $\gamma 2$ in the adipocyte. Further, metformin mediated AMPK-activation in adipocyte was inhibited by EECV treatment. It indicates that EECV increased the adipocyte differentiation and lipid accumulation via up-regulation of PPAR $\gamma 2$ by the inhibition AMPK- $\alpha$ expression.

Thiazolidinediones (TZDs) is types of insulin sensitizing drugs used for type 2 diabetes treatments and it ameliorate insulin resistance by promoting the adipocyte proliferation and differentiation through up-regulation of PPAR- $\gamma$ in the adipocyte. Further, it stimulates the adiponectin secretion in obesity animal model and humans [54,55] which activating the gene responsible for adipocyte differentiation. 27 muscle and adipose tissue possess the two kinds of glucose transporter such as GLUT-1 and GLUT-4 in which GLUT-4 is an important insulin regulator [56]. Down-regulation of glucose uptake in muscle and adipose tissue is an important reason for insulin resistance in type2 diabetes mellitus patients [57]. 


\section{A}

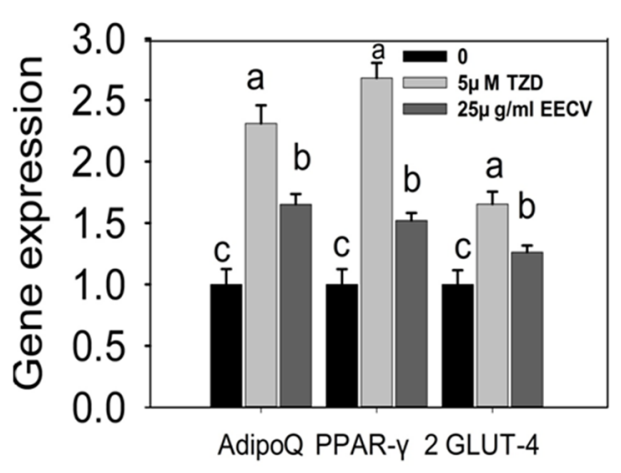

B

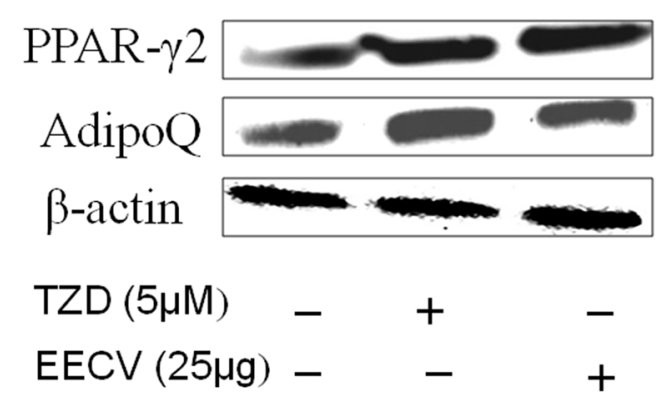

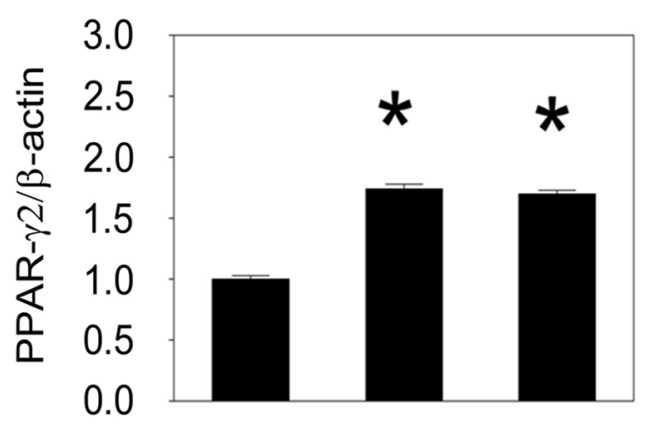

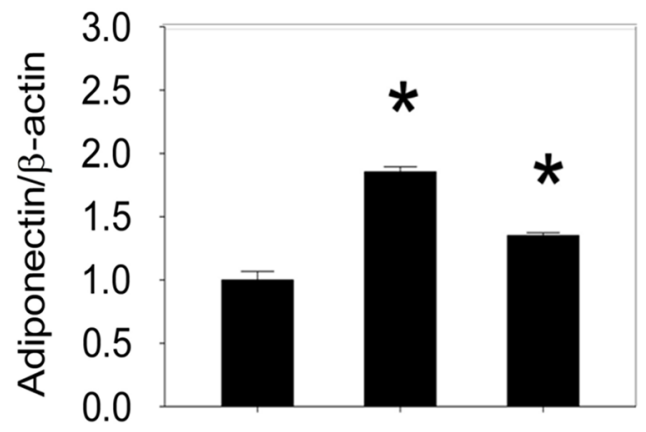

C

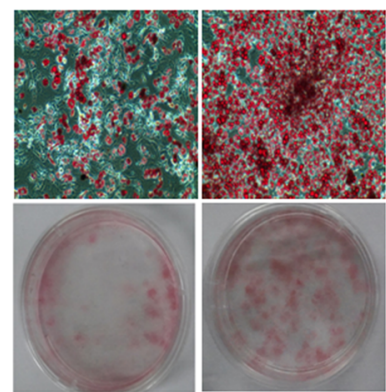

Control

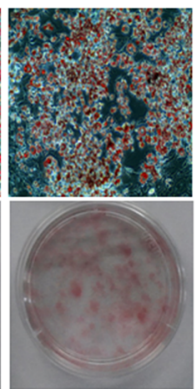

EECV $(25 \mu \mathrm{g} / \mathrm{ml})$
D

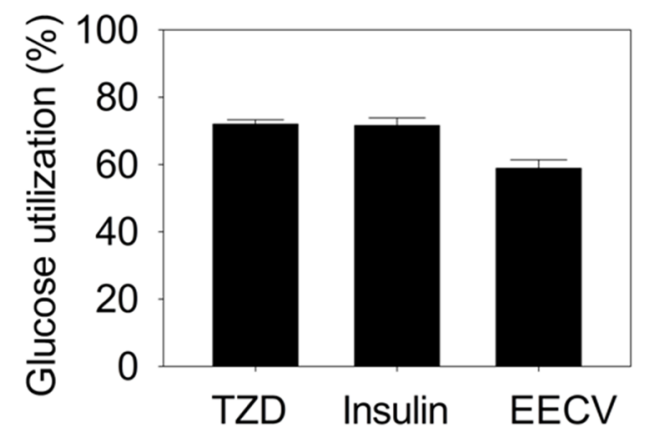

Fig. 6 EECV partially mimics like troglitazone. A PPAR- $\gamma 2$, adiponectin (adipoQ) and GLUT-4mRNA expression up regulated by the EECV (25 $\mu$ g/ $\mathrm{ml}$ ) and troglitazone (TZD) $(5 \mu \mathrm{M})$. B PPAR- $\gamma 2$ and adiponectin protein expression in control and experimental adipocytes. $\mathbf{C}$ Lipid accumulation in experimental adipocytes, D glucose utilization in differentiated adipocytes by TZD $(5 \mu \mathrm{M})$, insulin ( $1 \mu \mathrm{g} / \mathrm{ml})$, and EECV ( $25 \mu \mathrm{g} / \mathrm{ml})$. The results represent the mean \pm SEM of six replicates. ${ }^{*} \mathrm{p}<0.05$ compared to control adipocytes. Different letters $a, b, c$, within a treatment indicates significant differences $(p<0.05)$

The present study, troglitazone treatment stimulates the adiponectin, PPAR- $\gamma$, and GLUT-4 mRNA expression in the adipocyte. We found almost similar magnitude responses in EECV treatment; it stimulates the adiponectin, PPAR- $\gamma$, and GLUT- 4 expression. Further, the EECV enhances the glucose utilization in adipocyte through upregulation of adiponectin and GLUT-4 expression. Generally, GLUT-4 involved in transporting of glucose into adipose tissue and muscle [58]. These data suggested that
EECV increased glucose utilization in the adipose tissues via activation of adiponectin and GLUT-4 expression.

\section{Conclusions}

Type- 2 diabetes mellitus is closely associated with adipocyte differentiation. Insufficient adipocyte differentiation is one of the main reasons for developing type-2 diabetes. Any deficiency in the adipocyte differentiation causes fat depositions in the liver and muscle which are making 


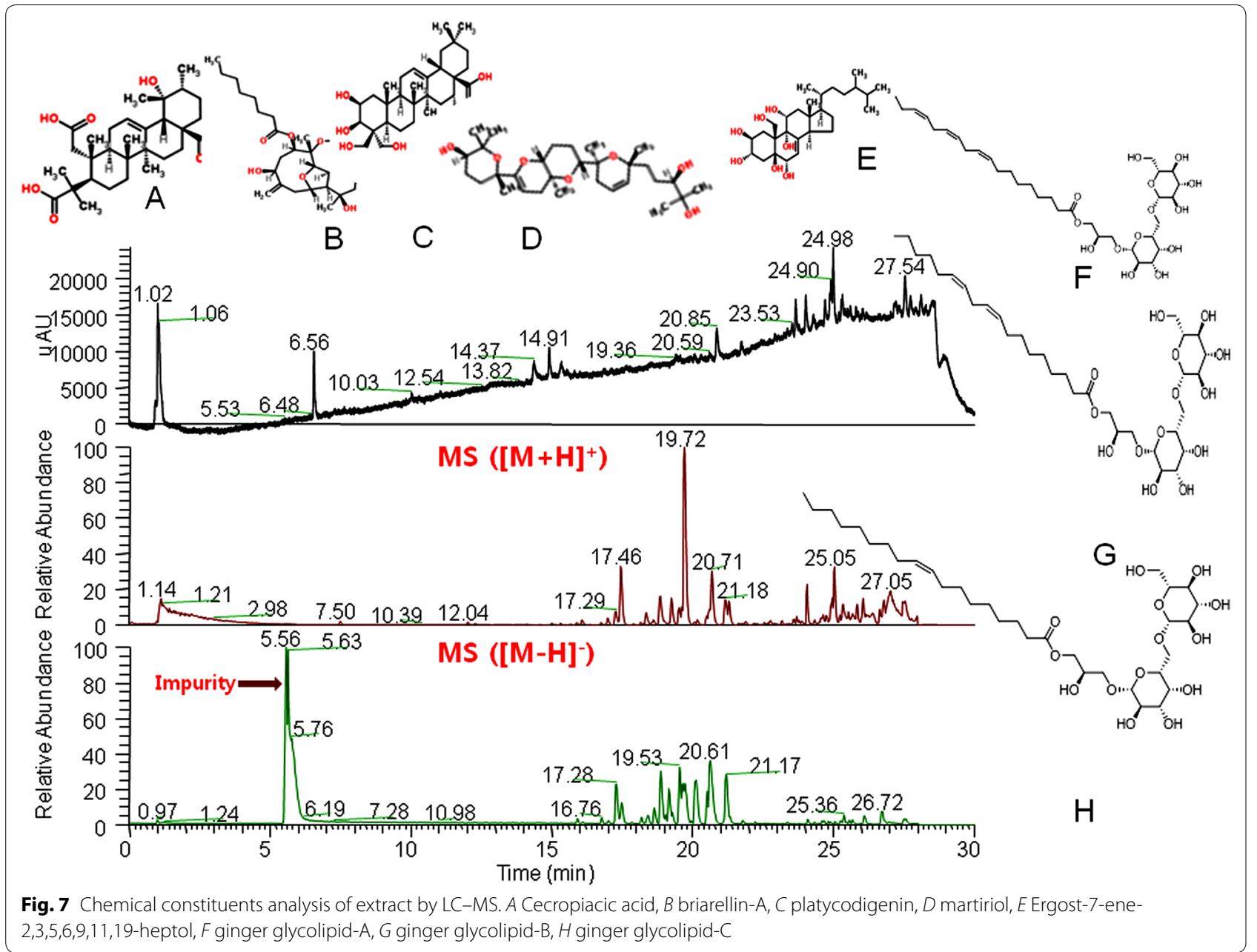

insulin resistance and type- 2 diabetes. The data presented in this study indicate that $C$. vulgaris effectively activate the adipocyte differentiation and glucose utilization. Further, we identified some of the triterpenoids and saponin compounds in this extract, which may be responsible for the positive regulation of adipogenesis. Hence, the present findings suggested that the EECV effectively modulates the lipid accumulation and differentiation in 3T3-L1 cells through AMPK- $\alpha$ mediated signalling pathway. Further, investigation needs to determine its active adipogenic molecule present in the C. vulgaris.

\section{Methods}

\section{Chemicals and cell}

The 3T3-L1 preadipocyte was obtained from the American Type Culture Collection (Rockwille, MD, USA). Dulbecco modified Eagle medium (DMEM) and fetal bovine serum was procured from Gibco-BRL (Gaithersburg, MD, USA). The EZ-Cytox kit, mRNA extraction and RT-PCR kits were purchased from Invitrogen (iTSBiO. Seoul, South Korea and Carlsbad, CA, USA). IBMX, Dexamethasone,
Insulin, troglitazone, oil red $\mathrm{O}$ stain, isopropanol and formalin were purchased from sigma Aldrich, USA).

\section{Extract preparation}

The C. vulgaris powder purchased from Daesang, Seoul, South Korea and it was soaked in $70 \%$ ethanol for $72 \mathrm{~h}$ at $37{ }^{\circ} \mathrm{C}$ by intermittent mixing using an orbital shaker. After that, the mixture was filtered using Whatman filter paper to separate the supernatant and the sediment. The filtrate was concentrated under reduced pressure at $40{ }^{\circ} \mathrm{C}$ until extraction solvent was completely removed, stored in refrigerator at $4{ }^{\circ} \mathrm{C}$ for further experiments.

\section{Cytotoxicity assay}

The water soluble tetrazolium [WST; 2[2-Methoxy-4nitrophenyl]-3[4-Nitrophenyl]-5-[2, 4-disulfophenyl]-2-Htetrazolium monosodium salt (EZ-Cytox kit) was used for analysis of cytotoxicity. The cells were seeded in the 96 well at a density of $1 \times 10^{4}$ cells/well. After, $24 \mathrm{~h}$, cells were exposed to the different concentration of EECV 5, 10, 15, 20, 25, 50 and $100 \mu \mathrm{g} / \mathrm{ml}$. It was incubated at the $37^{\circ} \mathrm{C}$ in 
$5 \% \mathrm{CO}_{2}$ incubator for $48 \mathrm{~h}$ and then the culture was treated with WST incubated for $2 \mathrm{~h}$. Then, the intensity of colour was measured at $450 \mathrm{~nm}$ using spectra count ELISA reader (Packard Instrument Co., Downers Grove, IL, USA).

\section{Cell culture and experiment}

Adipocyte differentiation experiment was carried out by the method of Choi et al. [59] with a slight modification. Briefly, 3T3-L1 cells were seeded in 12 well culture plates at a density of $1.5 \times 10^{4}$ cells/well. Cells were incubated at $37{ }^{\circ} \mathrm{C}$ with $5 \% \mathrm{CO}_{2}$ and culture medium was replaced by every $48 \mathrm{~h}$. After 2 days of $100 \%$ confluence of 3T3-L1 cells, the growth media was replaced by differentiation media (DMEM containing $10 \%$ FBS, 0.5 mM 3-isobutyl1-methylxanthine, $1 \mu \mathrm{M}$ dexamethasone, and $1.7 \mu \mathrm{M}$ insulin) for $48 \mathrm{~h}$. The pre-adipocyte were maintained and re-fed every $48 \mathrm{~h}$ with $10 \%$ FBS-DMEM medium. To examine the effect of EECV on adipocyte differentiation, the pre adipocyte received $5,10,15,20$ and $25 \mu \mathrm{g} / \mathrm{ml}$ EECV (in DMEM medium) every 2 days started at 2 days post confluence until the end of the experiment days.

\section{Quantification of lipid content by oil red 0 staining method}

3T3-L1 cells were fixed with $10 \%$ formalin for $1 \mathrm{~h}$. The cells were then rinsed with $40 \%$ isopropanol and $3 \mathrm{ml}$ of oil red $\mathrm{O}$ staining solution was added to each well, and incubated at room temperature for $15 \mathrm{~min}$ and then washed thrice with distilled water and photographed by an inverted microscope (CKX41, Olympus Corporation, Tokyo Japan). Additionally, oil red $\mathrm{O}$ stain was eluted from the adipocyte using isopropanol (100 \%) and measured at $490 \mathrm{~nm}$ [59].

\section{Measurement of glycerol accumulation}

According to adipolysis assay Kit procedure (CHEMI$\mathrm{CONH}$ International Inc. Temecula, CA, USA), the glycerol level was quantified. In detail, differentiated adipocyte in the presence of different concentration of EECV was washed twice with PBS (Gibco, Thermofisher scientific, Seoul, South Korea) and further incubated with lipolysis buffer for $1 \mathrm{~h}$. Then, the buffer was collected and measured the glycerol concentration using microplate reader at $540 \mathrm{~nm}$. The amount of glycerol was calculated using the standard curve of glycerol.

\section{Glucose utilization}

The differentiated adipocyte was exposed to high glucose $(25 \mathrm{mM})$ containing DMEM medium with EECV $(25 \mu \mathrm{g} /$ $\mathrm{ml})$, insulin $(1 \mu \mathrm{g} / \mathrm{ml})$ and troglitazone $(5 \mu \mathrm{M})$, individually for $24 \mathrm{~h}$. An assay, without EECV was considered as control. After $24 \mathrm{~h}$, the concentration of glucose in spent medium was estimated with a commercial assay kit (Sigma Aldrich-GAGO-20).

\section{Quantification of adipogenic gene expression using quantitative RT-PCR}

Cellular RNA was isolated from 3T3-L1 cells using the RNeasy lipid tissue mini kit (Qiagen, Valencia, CA, USA) according to the manufacture instructions. Isolated cellular RNA was measured by UVS-99 micro volume UV/ Vis spectrometer-ACT gene (ACTGene, Piscataway, NJ, USA). Five hundred nanogram of the cellular RNA was used for cDNA synthesis with oligo primer (dT) and reverse transcriptase (superscript III first strand synthesis system for RT-PCR)-Invitrogen. Real-time PCR was conducted using an ABI 7500 PCR system (Applied Biosystem, Foster City, CA, USA). The levels of target gene CDNA were measured by SYBR green-based real time PCR in $10 \mu \mathrm{l}$ of $5 \mu \mathrm{l}$ Power SYBR green-based mix reaction buffer (Biorad, Seoul, South Korea), 10 pM of forward $(\mathrm{F})$ reverse $(\mathrm{R})$ primers, $1 \mu \mathrm{L} \mathrm{cDNA}$ and $3 \mu \mathrm{L}$ DEPC water. All the expression levels were normalized to the housekeeping gene.

\section{Protein extraction and immune blot analysis}

Proteins from experimental adipocyte were extracted by RIPA lysis buffer with $1 \mathrm{X}$ protease inhibitor cocktail (Roche, Basel, Switzerland). The cells were washed with PBS for thrice. Then, added $500 \mu$ RIPA lysis buffer and incubated at $4{ }^{\circ} \mathrm{C}$ for five min. After that, cells were scraped rapidly with a cells scrapper to remove and lyse residual cells and transferred cell lysate to a tube for centrifugation at $4{ }^{\circ} \mathrm{C}$ for $10 \mathrm{~min}$. The total protein concentration was measured by a Bio-Rad protein assay kit. An equal amount of protein samples were separated by SDS-PAGE (10 \%) and trans blotted onto polyvinylidene difluoride (PVDF) membranes (iBlot gel transfer stacks, Novex, Life Technology, Waltham, MA, USA). According to western breeze chemiluminescence protocol (Invitrogen, USA), the immunobloting was performed (except primary antibody incubation time and temperature) with rabbit monoclonal antibody of specific proteins such as PPRA $\gamma 2, C / E B P-\alpha$, adiponectin, AMPK- $\alpha$ and $\beta$-actin (Cell Signaling Technology, Danvers, MA, USA). The signals were observed with an enhanced chemiluminescence kit (Biorad, Seoul, South Korea) by a chemiluminescence imaging system (Davinch Chemiluminescence, Seoul, South Korea) and the intensity of immune reacted bands was quantified by the ImageJ software- 1.49 version (32 bit), Wayne Rasband, National Institute of Health, USA.

\section{LC-MS/MS analysis}

The chemical constituents of EECV were analyzed by An API 4000 Q TRAP tandem mass spectrometer (Applied Biosystems, Foster City, CA, USA), equipped with an Agilent 1200 series HPLC system (Agilent 
Technologies) and with an electrospray ionization tandem mass spectrometry (ESI-MS/MS) source in positive ion mode $\left[[\mathrm{M}+\mathrm{H}]^{+}\right]$. The analytical conditions are: start $(100 \mathrm{amu})$, stop (1300 amu), and scan time (4.8 s); curtain gas, 20 psi (N2); heating gas temperature, $550{ }^{\circ} \mathrm{C}$; nebulising gas, $50 \mathrm{psi}$; heating gas, $50 \mathrm{psi}$; ion spray voltage, $5500 \mathrm{~V}$; declustering potential, $100 \mathrm{~V}$; entrance potential, $10 \mathrm{~V}$.

\section{Statistical analysis}

Each experiment was carried out in replicates $(n=6$; $\mathrm{n}=3$ ). Data are expressed as mean and standard error of mean (SEM). Statistical analysis was carried out using, Excel and one way ANOVAs and multivariate comparisons using the statistical package of social science (SPSS) program [Version 16.0] (SPSS, Inc., Chicago, IL, USA) and significance were represented as $\mathrm{p}<0.05$.

\section{Authors' contributions}

SI and DHK designed and performed the study, MV, MVA, SS, SGR and JSL helped in analyze the result, interpretation and draft the manuscript, KCC supervised, read and approved the final manuscript. All authors read and approved the final manuscript.

\begin{abstract}
Author details
${ }^{1}$ Grassland and Forage Division, National Institute of Animal Science, RDA, Seonghwan-Eup, Cheonan-Si, Chungnam 330-801, Republic of Korea. ${ }^{2}$ The United Graduate School of Agricultural Sciences, Tottori University, Tottori-Shi 680-8553, Japan. ${ }^{3}$ Laboratory of Animal Physiology, Graduate School of Agricultural Science, Tohoku University, Aoba, Sendai, Japan. ${ }^{4}$ Department of Botany and Microbiology, Addiriyah Chair for Environmental Studies, College of Science, King Saud University, Riyadh 11451, Saudi Arabia. ${ }^{5}$ Bio-center, Gyeonggi Institute of Science and Technology, Suwon, Republic of Korea.
\end{abstract}

\section{Acknowledgements}

This work was carried out with the support of "Cooperative Research Program for Agriculture Science \& Technology Development [Project title: Enhancement of nutrients in silage and development of technology for improvement of silage quality; Project No. PJ008445012013" Rural Development Administration, Republic of Korea. This study was supported by Postdoctoral Fellowship Program of [National Institute of Animal Science], Rural Development Administration, Republic of Korea. The authors extend their sincere thanks to Youjung Lee and Yousun Lee, Bergen Country Academy AMST for their contribution in this research.

\section{Competing interests}

The authors declare that they have no competing interests.

\section{Availability of data and materials}

All data and materials were given in the manuscript. We don't have further data and materials for sharing.

Received: 27 June 2016 Accepted: 22 August 2016

Published online: 07 September 2016

\section{References}

1. Trayhurn P, Wood IS. Signaling role of adipose tissue: adipokines and inflammation in obesity. Biochem Soc Trans. 2005;33:1078-81.

2. Smas CM, Sul HS. Control of adipocyte differentiation. Biochem J. 1995;309:697-710.

3. Ntambi JM, Kim YC. Adipocyte differentiation and gene expression. J Nutr. 2000;130:3122-6.
4. Dubois SG, Heilbronn LK, Smith SR, Albu JB, Kelley DE, Ravussin E. Decreased expression of adipogenic genes in obese subjects with type 2 diabetes. Obesity. 2006;14:1543-52.

5. Bays HE, Gonzalez-Campoy JM, Bray GA, Kitabchi AE, Bergman DA, Schorr AB. Pathogenic potential of adipose tissue and metabolic consequences of adipocyte hypertrophy and increased visceral adiposity. Exp Rev Cardiovasc Ther. 2008;6:343-68.

6. White UA, Stephens JM. Transcriptional factors that promote formation of white adipose tissue. Mol Cell Endocrinol. 2010;318:10-4.

7. Kahn BB, Alquier T, Carling D, Hardie DG. AMP-activated protein kinase: ancient energy gauge provides clues to modern understanding of metabolism. Cell Metab. 2005;1:15-25.

8. Daval M, Diot-Dupuy F, Bazin R. Anti-lipolytic action of AMP-activated protein kinase in rodent adipocyte. J Biol Chem. 2005;280:25250-7.

9. Gauthier MS, Miyoshi H, Souza SC. AMP-activated protein kinase is activated as a consequence of lipolysis in the adipocyte: potential mechanism and physiological relevance. J Biol Chem. 2008;283:16514-24.

10. Koh HJ, Hirshman MF, He H. Adrenaline is a critical mediator of acute exercise-induced AMP-activated protein kinase activation in adipocyte. Biochem J. 2007:403:473-81.

11. Ali MS, Jahangir M, Saleen M, Pervez MK, Hameed S, Ahmad VU. Metabolites of marine algae collected from Karachi-coasts of Arabian Sea. Nat Prod Sci. 2000;6:61-5.

12. Han JG, Kang GG, Kim JK, Kim SH. The present status and future of chlorella. Food Sci Ind. 2002;6:64-9.

13. Kang MS, Sim AJ, Chae HJ. Chlorella as a functional biomaterial. Kor J Biotech Bioeng. 2004;19:1-11.

14. Queiroz ML, Bincoletto C, Valadares MC, Antas DC, Santos LM. Effects of Chlorella vulgaris extract on cytokines production in Listeria monocytogenes infected mice. Immunopharm Immunotoxicol. 2002;24:483-96.

15. Lee HS, Choi CY, Cho C, Song Y. Attenuating effect of chlorella supplementation on oxidative stress and NF.kappa activation in peritoneal macrophages and liver of c57bl/6 mice fed on an atherogenic diet. Biosci Biotech Biochem. 2003;67:2083-90.

16. Shibata S, Oda K, Onodera-Masuoka N, Matsubara S, Kikuchi-Hayakawa $\mathrm{H}$, Ishikawa F, Iwabuchi A, Sansawa H. Hypocholesterolemic effect of indigestible fraction of Chlorella regularis in cholesterol-fed rats. J Nutr Sci Vitamin. 2001;47:373-7.

17. Lee HS, Park HJ, Kim K. Effect of Chlorella vulgaris on lipid metabolism in Wistar rats fed high fat diet. Nutr Res Prac. 2008;2:204-10.

18. Gregoire FM, Smas CM, Sul HS. Understanding adipocyte differentiation. Physiol Rev. 1998;78:783-809.

19. Balunas MJ, Kinghorn AD. Drug discovery from medicinal plants. Life Sci. 2005;78:431-41.

20. Mayer AM, Gustafson KR. Marine pharmacology in 2003-2004: antitumour and cytotoxic compounds. Eur J Cancer. 2006;42:2241-70.

21. Mayer AM, Hamann MT. Marine pharmacology in 2001-2002: marine compounds with anthelmintic, antibacterial, anticoagulant, antidiabetic, antifungal, anti-inflammatory, anti-malarial, antiplatelet, antiprotozoal, antituberculosis, and antivi-ral activities; affecting the cardiovascular, immune and nervous systems and other miscellaneous mechanisms of action. Comp Biochem Physiol C: Toxicol Pharmacol. 2005;140:265-86

22. Susanti D, Zaffar Ali M, Amiroudine M, FazlinRezali M, Taher M. Friedelin and lanosterol from Garcinia prainiana stimulated glucose uptake and adipocytes differentiation in 3T3-L1 adipocytes, natural product research: formerly. Nat Prod Lett. 2013;27(4):417-24

23. Niu CS, Yeh $\mathrm{CH}$, Yeh MF, Cheng JT. Increase of adipogenesis by ginsenoside (Rh2) in 3T3-L1 cell via an activation of glucocorticoid receptor. Horm Metab Res. 2009;41:271-6.

24. Shang W, Yang Y, Jiang B, Jin H, Zhou L, Liu S, Chen M. Ginsenoside Rb1 promotes adipogenesis in 3T3-L1 cells by enhancing PPARgamma2 and C/EBPa gene expression. Life Sci. 2007;80:618-25.

25. Cornelius P, MacDougald OA, Lane MD. Regulation of adipocyte development. Ann Rev Nutr. 1994;14:99-129.

26. Darlington GJ, Ross SE, MacDougald OA. The role of C/EBP genes in adipocyte differentiation. J Biol Chem. 1998;273:30057-60.

27. Lefterova MI, Zhang Y, Steger DJ, Schupp M, Schug J. PPAR gamma and C/EBP factors orchestrate adipocyte biology via adjacent binding on a genome-wide scale. Gen Develop. 2008;22:2941-52. 
28. Nielsen R, Pedersen TA, Hagenbeek D, Moulos P, Siersbaek R. Genomewide profiling of PPAR gamma: RXR and RNA polymerase II occupancy reveals temporal activation of distinct metabolic pathways and changes in RXR dimer composition during adipogenesis. Gen Develop. 2008;22:2953-67.

29. Valan Arasu M, Ilavenil S, Kim DH, Gun Roh S, Lee JC, Choi KC. In vitro and in vivo enhancement of adipogenesis by Italian Ryegrass (Lolium multiflorum) in 3T3-L1 cells and mice. PLOS ONE. 2014;9:85297.

30. Naowaboot J, Chung CH, Pannangpetch P, Choi R, Kim BH, Lee MY, Kukongviriyapan U. Mulberry leaves extract increases adiponectin in Murine 3T3-L1 adipocyte. Nutr Res. 2012;32:39-44

31. Korner A, Wabitsch M, Seide B, Fischer-Posovszky P, Berthold A. Adiponectin expression in humans is dependent on differentiation of adipocyte and down-regulated by humoral serum components of high molecular weight. Biochem Biophy Res Comm. 2005;337:540-50.

32. Fu Y, Luo N, Klein RL, Garvey WT. Adiponectin promotes adipocyte differentiation, insulin sensitivity, and lipid accumulation. J Lipid Res. 2005:46:1369-79.

33. Fruebis J, Tsao TS, Javorschi S, Ebbets-Reed D, Erickson MR. Proteolytic cleavage product of 30-kDa adipocyte complement-related protein increases fatty acid oxidation in muscle and causes weight loss in mice. Proc Nat Acad Sci USA. 2010;98:2005.

34. Berg AH, Combs TP, Du X. Brownlee M Scherer PE. The adipocyte-secreted protein Acrp30 enhances hepatic insulin action. Nat Med. 2001;7:947-53.

35. Kim S, Moustaid-Moussa N. Secretory, endocrine and autocrine/paracrine function of the adipocyte. J Nutr. 2000;130:3110-5.

36. Kallen CB, Lazar MA. Antidiabetic thiazolidinediones inhibit leptin (ob) gene expression in 3T3-L1 adipocyte. Proc Nat Acad Sci USA. 1996:93:5793-6.

37. Yu YH, Zhu H. Chronological changes in metabolism and functions of cultured adipocyte: a hypothesis for cell aging in mature adipocyte. Am J Physiol Endocrin Met. 2004;286:402-10.

38. Claycombe KJ, Jones BH, Standridge MK, Guo Y, Chun JT, Taylor JW, Moustaid-Moussa N. Insulin increases fatty acid synthase gene transcription in human adipocyte. Am J Physiol. 1998;274:1253-9.

39. Massiera F, Saint-Marc P, Seydoux J, Murata T, Kobayashi T. Rachidonic acid and prostacyclin signaling promote adipose tissue development: a human health concern. J Lipid Res. 2003;44:271-9.

40. Gustafson B, Jack MM, Cushman SW, Smith U. Adiponectin gene activation by thiazolidinediones requires PPAR gamma 2, but not C/EBP alphaevidence for differential regulation of the aP2 and adiponectin genes. Biochem Biophy Res Comm. 2003;308:933-9.

41. Hwang CS, Loftus TM, Mandrup S, Lane MD. Adipocyte differentiation and leptin expression. Ann Rev Cell Develop Biol. 1997;13:231-59.

42. Lakshmanan, Nepokroeff CM, Porter JW. Control of the synthesis of fatty acid synthetase in rat liver by insulin glucagon, and adenosine 30, 50 cyclic monophosphate. Proc Nat Acad Sci USA. 1972;69:3516-9.

43. Rubin CS, Hirsch A, Fung C, Rosen OM. Development of hormone receptors and hormonal responsiveness in vitro. Insulin receptors and insulin sensitivity in the pre-adipocyte and adipocyte forms of 3T3-L1 cells. J Biol Chem. 1978:253:7570-8.
44. Hardie DG. The AMP-activated protein kinase pathway-new players upstream and downstream. J Cell Sci. 2004;117:5479-87.

45. Chen S, Li Z, Li W, Shan Z, Zhu W. Resveratrol inhibits cell differentiation in 3T3-L1 adipocyte via activation of AMPK. Can J Physiol Pharmacol. 2011:89:793-9.

46. Lee YK, Lee WS, Hwang JT, Kwon DY, Surh YJ. Curcumin exerts anti-differentiation effect through AMPK alpha-PPAR-gamma in 3T3-L1 adipocyte and antiproliferatory effect through AMPKalpha-COX-2 in cancer cells. J Agri, Food Chem. 2009;57:305-10.

47. Habinowski SA, Witters LA. The effects of AICAR on adipocyte differentiation of 3T3-L1 cells. Biochem Biophy Res Comm. 2001;286:852-6.

48. Ono M, Fujimori K. Anti-adipogenic effect of dietary apigenin through activation of AMPK in 3T3-L1 cells. J Agri Food Chem. 2011:59:13346-52.

49. Kim SK, Kong CS. Anti-adipogenic effect of dioxinodehydroeckol via AMPK activation in 3T3-L1 adipocyte. Chem Biol Int. 2010;186:24-9.

50. Kong CS, Kim JA, Bak SS, Byun HG, Kim SK. Anti-obesity effect of carboxymethyl chitin by AMPK and aquaporin-7 pathways in 3T3-L1 adipocyte. J Nutr. 2011:22:276-81.

51. Hwang JT, Lee MS, Kim HJ, Sung MJ, Kim HY. Antiobesity effect of ginsenoside Rg3 involves the AMPK and PPAR-gamma signal pathways. Phytother Res. 2009;23:262-6.

52. Hwang JT, Park IJ, Shin JI, Lee YK, Lee SK. Genistein, EGCG, and capsaicin inhibit adipocyte differentiation process via activating AMP activated protein kinase. Biochem Biophys Res Commun. 2005;338:694-9.

53. Lee $H$, Kang R, Bae S, Yoon Y. AICAR, an activator of AMPK, inhibits adipogenesis via the WNT/ $\beta$-catenin pathway in 3T3-L1 adipocyte. Int J Mol Med. 2011;28:65-71.

54. Phillips SA, Ciaraldi TP, Kong AP, Bandukwala R, Aroda V, Carter L, Baxi S, Mudaliar SR, Henry RR. Modulation of circulating and adipose tissue adiponectin levels by antidiabetic therapy. Diabetes. 2003;52:667-74.

55. Maeda N, Takahashi M, Funahashi T, Kihara S, Nishizawa H, Kishida K, Nagaretani H, Matsuda M, Komuro R, Ouchi N, Kuriyama H, Hotta K, Nakamura T, Shimomura I, Matsuzawa Y. PPAR-gamma ligands increase expression and plasma concentrations of adiponectin, an adiposederived protein. Diabetes. 2001;50:2094-9.

56. Fukumoto H, Kayano T, Buse JB, Edwards Y, Pilch PF, Bell GI, Seino S. Cloning and characterization of the major insulin-responsive glucose transporter expressed in human skeletal muscle and other insulin-responsive tissues. J Biol Chem. 1989;264:7776-9.

57. Defronzo RA, Ferrannini E, Koivisto V. New concepts in the pathogenesis and treatment of noninsulin dependent diabetes mellitus. Am J Med. 1983;74:52-81.

58. McGowan KM, Long SD, Pekala PH. Glucose transporter gene expression regulation of transcription and mRNA stability. Pharmacol Ther. 1995:66:465-505.

59. Choi KC, Roh SG, Hong YH, Shrestha YB, Hishikawa D. The role of ghrelin and growth hormone secretagogues receptor on rat adipogenesis. Endocrinol. 2003;144:754-9.

\section{Submit your next manuscript to BioMed Central and we will help you at every step:}

- We accept pre-submission inquiries

- Our selector tool helps you to find the most relevant journal

- We provide round the clock customer support

- Convenient online submission

- Thorough peer review

- Inclusion in PubMed and all major indexing services

- Maximum visibility for your research

Submit your manuscript at www.biomedcentral.com/submit
(OioMed Central 